\title{
Forensic Practices and the "History of Justice" in the 17th and 18th Centuries: a View from a Spanish American Periphery
}

\author{
Agustín Casagrande
}

In recent years a tension has emerged between legal historians and social historians in the field of the history of justice. While the former have resorted to legal literature and judicial archives to observe how legal knowledge was applied in the practice of justice, the latter have privileged the field of archives without paying as much attention to the discourses that guided judicial praxis. In the latter case, the fundamental role played by a vital source - the forensic practices - has been neglected. This literary genre of the 17 th and 18 th centuries can serve to reconsider the relationship between legal literature and procedural practice which seems to be disconnected by the diverse prejudices created in pertinent disciplines of the academic field. So, by means of historiographicmethodological analysis, the aim of this chapter is to discuss certain elements to be considered in order to understand the oblivion with respect to the functionality of this type of literature ( 2 and 3 ). Such an analysis will then leave room for reconstructing the conceptual, intellectual and political conditions that served as a basis for the production of these texts (4). After a concrete analysis of the form that this type of literature took - by studying its writing conditions (5) - we will finally reflect on the uses that it can provide for writing and understanding the history of justice in marginal territories of the Spanish Monarchy (6) and (7).

"Practices": a Meta-Category in the Formation of a Disciplinary Field

One of the greatest tensions in the academic field today can be observed in the dialogue between the history of law and social history; above all, in the point made by social historians as to the lack of research on "practices" conducted by ius-historians. This criticism has a theoretical burden, which is sometimes 
forgotten due to the subjectivity that is constructed in university training. Thus, this tension must be considered to be part of the logic of the scientific field. ${ }^{1}$ In Argentina, this criticism has emerged in conjunction with the "new history of justice", which is based on the assumptions of social history. ${ }^{2}$ It can be observed, then, that this critique is defined by two elements. On the one hand, a process of professionalisation of historians has reinforced certain methodologies that are expressed in research topics and questions (popular culture, the lower classes, the actors, etc.). At the same time, this professionalisation was accompanied by a broadening of the social historical agenda towards the study of justice institutions. With respect to these new topics, it is worth noting that the field of justice was not a wasteland, since legal history had hegemonised the knowledge about law and political institutions until the latter half of the 2oth century. So one way to address this matter was through criticism.

The correlate of this academic dispute can be found in a critical formula used by social historians, which strategically reduced the procedures and investigations of legal history to a mere recounting of laws under a 19th century state paradigm - discourse - which had forgotten the practices, to be found in judicial archives, and ignored the living experience and reality. In addition to the attraction for the archive, which was constitutive of a disciplinary identity, a theoretical assumption claimed that practices were the only way of reconstructing the everyday experience of law. For that purpose, it was necessary to resort to a lens that isolated (inadvertent) practice from the discourse of normativity and centred it as a privileged object by contrasting it with the former.

In order to do this, historians turned to the sociology of practices. Some drew on the theory of Anthony Giddens, where the capacity of agency appeared as a determinant of a freedom to do things differently from the dictation of orders from above, thus rediscovering the "lost actors"; additionally, they relied on a more determining theory of habitus. ${ }^{3}$ By obliterating the debate on the crossroads of the actor with the social and institutional structure, it allowed an unusual recovery of the daily practices in the category, no less problematic, of extended practices which were crystallised in the form of the customary/

1 For the use of this category, see Bourdieu, "Le champ scientifique".

2 From the French and Spanish tradition, see the recent work of Barriera, "La historia de la justicia y las otras historias". Some classic texts from the tradition of the New Legal History are: Buffington, "Introduction"; Aguirre and Salvatore, "Writing the History of Law, Crime, and Punishment in Latin America"; Palacio and Candioti (eds.), Justicia, política y derechos en América Latina.

3 Giddens, The Constitution of Society. See also Bourdieu, El sentido práctico. 
habits. ${ }^{4}$ Thus, the scientific field produced a contraposition between practicescustom versus discourse-law which would open a hiatus in the appreciation of the judicial phenomenon.

However, it was not sociology that allowed the social historisation of the juridical but the influence of British cultural Marxism, which reached the pampas through the feverish reading of Edward Palmer Thompson. ${ }^{5}$ Following this key author, Argentinian historians began to see custom as the practice that acted in a zone of friction between men and the law. However, in order to define custom, no complex legal concept was used; ${ }^{6}$ rather, the semantic content of this legal institution was reduced to an operative category, presenting it as the result of the elementary exchanges of material life, with no connection to the influence of high culture. ${ }^{7}$ It can be seen, then, how the theory allowed the appearance of a pure practice underlying the normative power of custom. In this way, beneath the veil of custom the know-how of rural - rustic - people could be revealed. Such "real acts" could only be found in the archives, and mainly in view of the judicial sources, which in their daily life and repetition showed how order and justice were "really" experienced in spaces far away from the high technology of literate knowledge. ${ }^{8}$

This theoretical activity presents a few drawbacks. So, in order to describe them, the theoretical basis for the discovery of pure practices must be deconstructed. Recently, in a criticism of romanticism and the reification of the concept of Thompsonian custom, Paola Miceli has pointed out that:

4 As an example, see the first pages of Raúl Fradkin's excellent and classic work, "Ley, costumbre y relaciones sociales en la campaña de Buenos Aires (siglos XVIII y XIX)”, in Fradkin, $L a$ ley es tela de araña.

5 Thompson, Costumbres en Común. It should be noted that the critical aspect of this essay does not rule out E.P. Thompson's fundamental contribution, especially considering his attempt to rethink the role of superstructural elements in the shaping of legal experience, and thus returning a cultural character to law that had been reduced to a mere response of the economic structure by traditional Marxism. On this last point, see V. Tau Anzoátegui's reflections, referring to Le Goff, in Tau Anzoátegui, La ley en la América Hispana, 3-7.

6 On the problem of custom and the exhaustive problematisation of the diverse theoretical keys that surround the phenomenon, Paola Miceli's study is fundamental; see Miceli, Derecho consuetudinario y memoria, 27-72.

7 Cerutti, "Histoire pragmatique, ou de la rencontre entre histoire sociale et histoire culturelle", 151 .

8 The construction of this particular object - village - emerges from a double isolation. On the one hand, from the bourgeoisie, which becomes an anachronism and, on the other, from the scriptural world, where textuality is isolated from a broad register that coexists with the literate; so a voice reappears that is characteristic of the agent detached from culture. The risk seems to be that this tends to become - through the writing of its history - the "copy of the artefact" that produces it; see De Certeau, La invención de lo Cotidiano, 146. 
From the title of his introduction: "Customs and Culture", we can clearly see what is the prevailing notion of custom in Thompson. Custom is the reservoir of tradition, which is used by those who cannot access systematic education. Custom includes the traditional habits and customs of the people as opposed to knowledge transmitted by elitist mechanisms. The relationship that is immediately established is between custom, culture and people. The custom is, thus, popular culture, the set of experiences and practices transmitted from generation to generation as systematic teaching through non-systematic channels. A romantic touch surrounds this statement: for Thompson, custom is an environment of uncontaminated behaviour, the moment or place where human nature is expressed. ${ }^{9}$

The consequence of the link between custom-culture-village and its resulting "uncontaminated sphere of behaviour" as opposed to "knowledge transmitted by elitist mechanisms" produced, as Peter Burke points out, a split between popular culture and high culture. ${ }^{10}$ This separation that knocks at the doors of academia would serve to define an analytical procedure. But in Thompson's thought there is something else. By deconstructing it, Simona Cerutti reveals the base of this theoretical scheme:

The tradition of the School of historical law, which strives to revive the popular roots of law - Thompson's first source of inspiration is Marx, a student of Savigny. From this intellectual tradition, Thompson adopts a crucial presupposition, the popular character of "alternative" cultures; which means the existence of a link between the plebs (the ensemble of groups excluded from power) and conceptions of law that are "other" than those legitimized by the texts. ${ }^{11}$

This sliding from Thompson to Marx, and from Marx to Savigny, facilitates an understanding of the original division between two different cultures, which found in the customary voice a romantic conception of a popular act, serving as a base to construct a dichotomy between the field of pure practices and the textual universe of elites.

9 Miceli, Práctica jurídica y costumbre en Castilla y León, 43-44.

10 Burke, Was ist Kulturgeschichte?, 38-40.

11 Cerutti, "Histoire pragmatique, ou de la rencontre entre histoire sociale et histoire culturelle", 152 . 
That theory gave rise to several consequences in Argentina, specifically, in the field of the "new history of justice". The first was the separation between a legal culture - based on practices - and a legal culture - as producer of discourses - which, under the theoretical assumption of corresponding to alternative cultural formations, fragmented the legal phenomenon, making invisible, in some cases, a connection between texts, institutional pressures, forms of knowledge circulation, etc. The second, rather methodological consequence was the difficulty to integrate the use of diverse sources in the same study. That is to say, to compose what can be said of a historical phenomenom beyond the "voice" of the actors, by means of juridical books, legislation, confession manuals, etc. Consequently, given that the production of a lay culture was derived from material relations, any other product was a replica or contamination, something that deserved to be reduced as much as possible.

Thus, the seemingly innocuous expression of "discourses and practices" as organising categories of what can be observed in research has a surplus of meaning, which conceals a dense legal debate on the sources of law originated in the 19th century. If the accusation against a state-oriented legalist history of law resulted in new advances in research, this criticism should not replicate another contribution of the 19th century. Thus, the dismantling of another 19th century foundation - that of the historical school of law - can make some points appear occluded by the category of "pure practices", which deserve to be thematised.

\section{3 "Forensic practices": a History of Oblivion}

Beyond those theoretical elements which constitute the institutional logic of social history, a distrustful or even derogatory view of practical literature has also been presented within the literary legal history. This point can find some explanation for the taxonomic impulse of contemporaneity. In the task of isolating and cataloguing books, some genres (such as the forensic practices) have been put in a marginal place after comparing them with the great theoretical and dogmatic works of the time. ${ }^{12}$ The fate of this juridical literary genre is not paradoxical, given that although it is recognised as having circulated widely, ${ }^{13}$ its little dogmatic importance seems to have condemned these works to occupy the last step of a process that, by traditional juridical history

\footnotetext{
12 On this subject, see the classic and fundamental work of Tomás y Valiente, El derecho penal de la Monarquía absoluta, 139-149.

13 Cutter, The Legal Culture of Northern New Spain.
} 
was characterised as vulgarisation. ${ }^{14}$ To analyse the role of this kind of literature through this process seems to conceal the rich and complex process of distancing between theory and praxis that would be a characteristic note of the 18 th century experience.

However, this is not only attributable to legal historiography. Cultural history has also adopted this perspective with similar effects. As an example, we can refer to a detailed study and evaluation of the legal books held by the capitular clergy of the Toledo cathedral, conducted by Ramón Sánchez González, who states:

It will be precisely the genre of forensic practices - that is, the attempt to know more about the legal praxis expressed through the formulas mentioned above, which establish a doctrinal corpus with which lawyers acquire fluency in the way of acting but they ignore the scientific foundations of these actions which leads to a process of cultural impoverishment. ${ }^{15}$

A brief analysis of these models presents the problem of understanding the emergence of this practical literature as a record of "cultural impoverishment", without stressing that, perhaps, the simple discourses conveyed by these works were the consequence of the action of a context of power that prevented long theoretical excurses. Thus, more than an impoverishment - a word that manifests a certain nostalgic teleology - the extended use of these texts could be indicative of changes in the political-legal power that were inscribed in a particular discursive formation - explicative for other than this literary genre and that deserves to be reconstructed.

For its part, from the perspective of social history, although the significance of these forensic practices has been recognised, their value as a cultural object worthy of analysis has been reduced by methodological means when compared with the wealth provided by judicial archives. ${ }^{16}$ In this second case, the fact of

\footnotetext{
14 Bernal, "Las leyes de indias a la luz de dos comentaristas novohispanos del siglo XVIII". For the analysis of "vulgarization", see Christoph Meyer (Chapter 2) in this volume.

15 Sánchez González, "La cultura de las letras en el clero capitular de la catedral toledana", 193 (italics do not appear in the original). Even a brilliant scholar of the subject like Tomás y Valiente, in his commentary, and in spite of recognising the link between the growth of the King's power and the appearance of such a pragmatic literature, warns that: "These men of the non-university forum are with certain frequency expressedly authors or addressees of some Prácticas or Sumas judiciales that break with the old style and incur at the same time in the already mentioned scientific mediocrity", in Tomás y Valiente, El derecho penal de la Monarquía absoluta, 140.

See the excellent work of Barriera, "Voces legas, letras de justicia".
} 
presenting them in close relationship with judicial practice - but no longer as a formative element of it but as a subsidiary factor to interpret the sources available to the researcher - impoverishes the network of referrals between sources.

Based on what has been said in the previous sections, some questions can be postulated. In the first place, and given that the notion of pure practices turned out to be a replica of a 19th-century Savignian "invention of tradition" linked to custom, from the Hispanic legal tradition it is worth asking what was understood by 'practice' and 'custom' in the Castilian and Spanish American world of the 18th century. Correlatively, it is necessary to ask if there was a total discontinuity between lay and literate cultures and, from the revision of this presupposition, it is possible to enquire into the role of a practical literature in the political context of the 18 th century. This will try to overcome the forms of teleology that the disciplinary gaze casts on this narrative. So, the juridical matter could be considered as a discourse of power, which allows the supposition of a very pronounced dynamic that includes institutions, actors and discourses in each instance of action. Therefore, we should begin by trying to answer the first question: what was understood by 'practice' in the 18th century?

\section{Practice as a Concept: Reassembling the Romantic Prejudices}

Given the mentioned difficulty concerning the meaning of two basic concepts of the juridical culture of the 18th century - custom and practice - which extend to the present reinterpreted in the light of the romanticism of the historical school, it is worth carrying out a very brief historical-conceptual exercise to clarify any doubts and to reach the central problem of judicial praxis. To this end, although being aware of the diverse layers of meaning stratified in the concept of custom, the operation proposed here is very simple: to resort to dictionaries. It is worth mentioning that this source must be treated very carefully. Although, methodologically, they had become indexes of concepts inserted in another period, their definitions do not manage to capture the total complexity of a language of a time, which is in constant mutation. Besides, dictionaries were not at all politically innocuous. With this clarification, it cannot be denied that in the dictionaries, 'custom' possesses a large dose of 'practice'. But this practice that sediments custom cannot be defined only by its iterative character. Thus, although in the second entry of the lemma "práctica" of the Diccionario de Autoridades of 1737 , it can be read that this one "means also the continued use, custom or style of a thing", ${ }^{17}$ which seems to confirm the 
Thompsonian sense; in the same work, the second entry of "costumbre" - corresponding to the juridical sense - indicates that:

It is also valid as a fuero, an unwritten right or law, which has the same force, and produces the same effect as it, as long as it is introduced with the circumstances or solemnities provided in law. First, that it be about a point or a thing of which something good is derived. Second, that its use or exercise be public; Third, that it be admitted with the will of all persons who make up the Pueblo or Province where it is established, or at least of the greater part; Fourth, that it does not oppose or contradict the rights or laws written; Fifth, that it is permitted or tolerated by the Lord of the Pueblo. ${ }^{18}$

The comparison between the second definition of "costumbre" and the second definition of "práctica" - charged with a "solemnity provided in law" - makes visible some elements that need to be explored. From a logical point of view, the dictionary sentence exhibits a tension between written law and custom within the sources of pre-modern law. At this level, although both terms are found in the paragraph, there is a growing weight of the power of the former with respect to the latter, which, while not ruling out the significant role of custom, at least moderated it. There, the power of custom seemed to require a process of juridical qualification, which implied that the habitual and repetitive actions to be converted into law, had to be filtered by a knowledge that was composed of laws and reasons of justice. ${ }^{19}$ Indeed, the Diccionario de Autoridades stated that there was a recognised custom "when there is no law to the contrary, nor that it repulses reason and justice". Thus, it can be perceived that although every custom required 'practices', not every group of 'practices' per se could become custom, but only those that, in dialogue with the law and the concepts of reason, were tolerable. This last point, precisely, invites reflection on the concept of practice, given that if it seems that customary law refers to

18 Real Academia Española, Diccionario de la lengua castellana, vol. 2, 1729, 643: "vale también fuero, derecho ù ley no escrita, que tiene la misma fuerza, y produce el mismo efecto que ella, con tal, que se introduzca con las circunstancias o solemnidades prevenidas por derecho: Primera, que sea sobre punto ò cosa de que se pueda seguir algún bien; segunda, que su uso ò exercicio sea público; tercera, que se admita con voluntad de todas las personas que componen el Pueblo ò Provincia donde se establece, ò á lo menos de la mayor parte: Cuarta, que no se oponga o contravenga a los derechos o leyes escritas, quinta, que la permita o tolere el Señor del Pueblo [...]".

19 See Thomas, "La valeur des choses", 1449-1450; Miceli, Derecho consuetudinario y memoria, 20. 
an ordo iuris, possibly the practices - the last and formative instances of the former - could present a similar content. That is to say, within this cultural enclave it should not be surprising that the practice possessed a determining relationship with a knowledge that qualified it as such. What, then, did the dictionary say about 'practice'?

The main entry of the 1737 edition described "practice" as "the exercise, or actual execution, according to the rules of some Art or Faculty, which teaches to do something, as a consequence of the theoretical. It is from the Latin Praxis, which means the same thing". ${ }^{20}$ The close relationship between theory and practice was essential for thinking about exercising something, or simply acting. Instead of projecting a limit on the contamination of an external knowledge to the practices themselves, these could not be conceived without the guidance of rules consistent with a theory. It was just towards the middle of the 19th century, precisely between the edition of the Dictionary of the Royal Academy of 1843 and that of 1857 , when this relationship disappeared, leaving a simplified term that is closer to our present understanding: "The exercise of any art or faculty according to its rules. Praxis". ${ }^{21}$ Clearly, in the course of little more than a century, the dislocation of a tradition and the conceptual mutation implied by semantic displacement caused the theoretical to be lost as an essential datum that refounded practice in knowledge, finding in its definition the notion of an act according to a simple rule.

As it appears at first glance, the course of this voice is complex. Hence, in order to perceive that change that would bring the praxis closer to techné, it is necessary to observe a greater field where dislocation is generated: politics. ${ }^{22}$ The displacement, which took place in the 18 th century and which follows a winding road of more than 18 centuries, has the Aristotelian praxis as its starting point. ${ }^{23}$ At this extreme, it cannot be ignored that, for this tradition, practical philosophy could not be separated from politics. Thus, between ethics and politics there was no distance or dialectic, but rather a continuum based on experience. In this context, praxis was a moral action, where acting had an end in itself. This nature separated it from poiesis, which approached the action of

$20 \quad$ Real Academia Española, Diccionario de la lengua castellana, vol. 5, 1737, 344: "El exercicio, ù actual execución, conforme à las reglas de algún Arte o Facultad, que enseña à hacer alguna cosa, como consiguiente à la Theórica. Es del Latino Praxis, que significa lo mismo".

21 Real Academia Española, Diccionario de la lengua castellana, 1852, 556.

22 This aspect has been intensively studied by Sandro Chignola and Giuseppe Duso. See Chignola and Duso, Historia de los conceptos y filosofía política.

23 For a reconstruction of this long evolution, see Bien, Kobusch and Kleger, "Praxis, praktisch". 
the craftsman, who produces something that comes into existence outside the agent of his acts. In this sense, it should be remembered that for Aristotelian thought, praxis was separate from "simple techné", since the former depended on the knowledge applied for a good life. This implied seeing politics as a pedagogical formation of character that led to a phronesis, that is, to achieve "a wise understanding of the situation; phronesis, on which the tradition of classical politics is based from Cicero's prudence to Burke's Prudence". ${ }^{24}$

Now, simplifying to the extreme the course of philosophical thought, one can see a fundamental logical split established by modern political science, anticipated by Hobbes in the 17th century and developed by the discipline of public law during the 18 th century. ${ }^{25}$ In this sense, the action of this new knowledge would have an impact on some correlative points. This key voice of prudence, seen as a virtue, would be gradually relegated by a knowledge of the political technique intended to ensure the organisation of the State. In this way, knowledge would emerge by abjuring the classical political tradition, and influenced by the sciences of nature and mathematics, leaving praxis in a field close to techné. ${ }^{6}$ Thus, the logic of government would be transformed from prudence to technique, where praxis instead of referring to the former would be ordered by the latter. In this context of radical change in modes of thought, it can be seen that the links between practice and theory and between practice and technique encompassed a logic of government that at the same time overlapped with the legal sphere. This shift also is implied in our present understanding; therefore, to make it explicit would serve to recognise a distinctive way of understanding "practice" in a cosmovision still anchored in the old tradition. Besides, it serves as a warning about the complexity that describing and analysing the shifting structure of a rich concept of praxis in the selected period is exposed to theoretical problems starting from a conceptualisation loaded with topicality.

At this point, and if this historical-philosophical excursus is of vital importance as context, the categorical-conceptual uses of praxis and theory within the judicial field requires other sources where the tense relationship between theory and practice is expressed in a more specific way. It is precisely here that the forensic literature appears. This special juridical literature, which strongly circulated since the beginning of the 18th century and continued to do so throughout the 19th century, takes on a fundamental dimension because it enables the connection of political-juridical knowledge with the judicial sphere,

\footnotetext{
24 Habermas, Teoría y praxis, 49-5o.

25 Duso, La lógica del potere.

26 Habermas, Teoría y praxis, chapter I.
} 
which in turn leads one to look for the historical-philosophical relation between theory, discourses and practices.

The complex relationship between theory and praxis was a common base for practical literature, which defined its literary status at these crossroads. Thus, in order to judge its quality, it was less the erudition of the author that counted than the more modest characteristic that looked at the "usefulness" of the work. This topic, ubiquitous in the references to the works, did not mean to propose interpretations or new doctrines but it privileged the collection of "disseminated knowledge" in order to present them in a simplified and orderly way, and in a discourse tending towards a concrete end: judicial performance. This purpose defined the substantial problematic of the works, concentrated on know-how, and delimited a style that left little expressive space to the author. ${ }^{27}$ Thus, restricted by powers that ordered the discourses - the need for print approvals, as well as the hidden judgments after publication - the authors strove to justify the need for their works. However, in the course of the 17th century and until the end of the 18th century the meaning of judicial action was modulated by the progressive dissolution of a long experience of political government and by the emergence of a judicial practice that sought to conform to the power of law. In those interstices a slow process began that resulted in the reduction of the semantic field of judicial praxis.

\subsection{From Theory to Observation: Moments of Practical Knowledge}

Given the theoretical problem, expressed by the distance between "discourses and practices", referred to at the beginning of this chapter, the first point to highlight is the link between forensic practices, especially criminal ones, and the concept of praxis with Aristotelian roots, which, as was indicated, could not consider the latter outside the theory. Going back to works written during the 17th century, one observes that such a connection of meaning was decisive. Gerónimo Fernández de Herrera Villarroel expressed this in the "Prologue to the Reader" of his Criminal Practice approved in 1671, of which the 1724 edition is used here:

27 As Bajtín, Estética de la creación verbal, 252, pointed out, "in the great majority of discursive genres (except literary genres) an individual style does not form part of the intention of the enunciation, it is not its sole purpose but rather it turns out to be, so to speak, an epiphenomenon of the enunciation, a complementary product of it". 
All art, and craft, be it speculative, theoretical, as well as practical, contains in itself science, without obscuring the distinction that there is no such thing without a divine object (reputing even the most famous for mere art) because without contradicting questions, which result from here, I take it for the extension of its common meaning in all genre, which is enough for my attempt; with which I will say, that to obtain the perfect thing of any Art, or business, the one who exerts it must have science of it, because this is the point of the elevation, or the center of the success, its opposite reverse the ignorance: To arrive from this to that, one disposes the desire, but alone it is not enough without continuous fatigue. ${ }^{28}$

This literature came to occupy a space in the judicial world that would free the reader from ignorance. However, the excess of theory also complicated the experience of justice. Thus, the opinion of the various authors could also lead to a problem of their own making. The task of the author of these works seemed to be defined by the gathering of multiple forms of knowledge in order to simplify them. It was precisely this last point that became the subject of Villadiego's work approved in 16o9; in his note to the Reader, he said:

I have tried in this Political Instruction and Judicial Practice, taking advantage of other books of much erudition, reducing here to a compendium and brief suma the most substantial, which in them is very extended, and I remember Seneca's sentence, which says that it is more useful to know few precepts of doctrine and wisdom, and to be soon in them, than many, not having them at hand. ${ }^{29}$

Defined between these lines is the problem that the abundance of texts, dogmas and doctrine entailed for the desired judicial action. Hence, without conceiving an act outside the knowledge composed by doctrine, the excessive amount of information seemed to cloud the gaze of justice. With this, the perfect procedural rule sought to harmonise the theory in order not to divert the practice, as well as to avoid the ignorance of the basic knowledge of dispensing justice. Both correlative dimensions of political government were made comprehensible from a community of theory and practice that guided legal prudence, from a politically guided government. Hence, its proximity

28 Fernández de Herrera Villarroel, Practica criminal, instrucción (nueva útil) de substanciar las causas, Prólogo.

Villadiego Valcuñana y Montoya, Instrucción Política y práctica judicial, Prólogo. 
to the works of the political government such as that of Castillo de Bovadilla was manifest. Political government and judicial practice, as the title of Villadiego's work pointed out without gratuitousness, showed a jurisdictional logic. ${ }^{30}$

Towards the end of the 18th century, this tension was still inscribed in the writers' messages. However, a glance at the everyday life of the courts showed a tendency to see practices repeated by mere observation, which had to be corrected by the guidance of a just doctrine (precisely the doctrine that these same authors promoted). Antonio de Elizondo said, in volume IV of the 1784 edition of his Práctica Universal Forense, that:

The good and the utility of the industrious youth have been the objects, that we propose to attend in this work, where, without the need of resorting to immense commentaries, it is easy to discover a national practice adjusted to the frequent sponsorship of the cases, cutting the occasion to consume the time in investigating the styles, and excusing the young people to beg these news from some people, whose elusive instruction cannot give them more support than that of the simple and naked observation, of how much they saw other Curiales perform in their days. ${ }^{31}$

On sharing that cultivating gaze of youth, and being aware of the need to avoid the errors produced by mere "execution" without proper guidance, Alvarez de Posadilla wrote, in his mid-18th century Práctica Criminal, that:

In order that the young people take advantage of it, it has seemed convenient to give it in the form of dialogues, as it was written for the principal and first disciple of this teaching, that read by way of entertainment, insensibly instruct them, and know, at the same time as exercising themselves in practice, the abuses that they see observing their Masters, and avoid receiving the error and abuse of doctrine. ${ }^{32}$

30 On this perspective, see Costa, Iurisdictio. With a link to the history of Justice in Spanish American territories, see Agüero, Castigar y perdonar cuando conviene a la República; Garriga, "Sobre el gobierno de la justicia en Indias".

31 Elizondo, Práctica, vol. 4, vir. Here, "style" resembles a practice that can be observed juridically. So, "estilo" was not only a note of particularity or distinction but, as stated in Real Academia Española, Diccionario de la lengua castellana, vol. 3, 1732, 635: "en lo legal es la fórmula de proceder jurídicamente, y el orden y méthodo de actuar". 
Instruction for practice is proposed as a remedy for errors learned by observing the masters. Here, it would seem that the problem was not so much ignorance, but rather that the damage came from the "error and abuse of doctrine".

From this vantage point, it becomes clear that between the first written practices of the 17th century and these other ones from the middle of the 18th century a gap opened with regard to the legal understanding of practices. While in the former the knowledge-politics-practice correlation was indispensable, in the latter there was talk of an observation of acts in the Tribunals, which would open a furrow between knowledge and practice, defining new conceptual contents, which were nothing trivial. But this can only be understood within a complex political history of the conceptual formation of practice separated from theory.

\subsection{From Politics to Practices: a Writing Order}

Contextualisation and diachrony allow us to postulate certain premises in order to understand the process of isolation of "practice" with respect to theory within the legal field. In a first level of analysis, and by means of a long-term view, it is possible to comprehend that both this literature and these authors were exposed to a growing process of hermeneutic control that, throughout the 17th and 18th centuries opposed statutory law to the jurisdiction, assessing the Monarch's power in terms of his potestas legislatorial. ${ }^{33}$

In this context, and knowing that all these books had to be submitted for approval, the literary structure was modified by the authors, showing that, beyond a process of "vulgarization" or scientific "advancement", it was the dynamics of political power what was incorporated into the mutated discursive structure. For example, it is noteworthy that, by concealing the reference to the prudence of the "authors" and highlighting instead that the procedures were useful to make the "Laws of the Kingdom" operative, a faster edition could be achieved and, at the same time, a consecration by way of a reference book. The sources seem to demonstrate that extreme. While the practices of Villadiego and Fernández de Herrera Villarroel can be seen as being close to political government during the $17^{\text {th }}$ century, ${ }^{34}$ in the 18 th century the books remarked

33 On this development, see the indispensable study by Mohnhaupt, "Potestas legislatoria und Gesetzesbegriff im Ancien Régime".

34 For example, Villadiego, whose work did not coincidentally include in its title "politics and practice", explained that his book consisted of "the real laws by which lawsuits and causes must be judged and abrogated and substantiated first than by those of derecho común" (which left room for the consideration of the literature that conveyed the latter). For his part, Fernández de Herrera Villarroel stated that jurisdiction should be protected against those who altered justice, where prudence and calm were the pillars of a good 
that it was the law and its enforcement which guided the strict "administration of justice". 35

On a second level, this process of mutation can be seen within the dynamics of the juridical literary field, which, without disassociating itself from the political, allowed greater pertinence to analyse the development of a concept of practice within the discipline. In order to do this, it is necessary to bear in mind that the composition of this particular literary genre was determined by the recognition and intertextuality between the works. ${ }^{36}$ In this way, the 18th century references to previous texts offer clues to understanding, on the one hand, how the literary tradition was constructed; and, on the other, how a differentiation process would, despite sharing a common core, have an impact on the conceptuality of each work. An example can clarify this dimension. In 1754, Berní wrote in the introduction of his practice, which was widely disseminated:

Nearly all the laws of the Kingdom seek the extinction of abuses and crimes; and all together they establish right administration of justice. Their glossators adapted infinite doctrines; and for greater clarity, in matters of crimes, Farinacio wrote six volumes of Criminal Practice; Antonio Gomez wrote the third one of several; Mr. Mateu a work de re criminali; Leotardo, one work de usuris \& contractibus; and in order to put the penalties into practice, Peguera, Gutierrez, Salcedo and Herrera wrote their books. ${ }^{37}$

Fernández de Herrera Villarroel thus became an antecedent for intertextual connection, but for a mid-18th century author the work of the former was not enough. Thus, Berní later said: "I have read these works, and I form a concept, that the present Practice will not be despicable; because in addition to reducing to an easy and clear method the matter of crimes, penalties, legal presumptions, and defences, with the most solid foundations, the practice observed today in the Royal Courts of Spain is added". Berní discredited Fernández de Herrera Villarroel just as soon as he had been instituted, by placing him on the side of doctrine, which would be discredited in the face of the emergence

judge. A clear jurisdictional culture, of which the indications to be recognised require a heuristic exercise of translation by means of models. For the context, see the great synthesis Agüero, "Las categorías básicas de la cultura jurisdiccional".

35 See Álvarez de Posadilla, Práctica criminal por principios, 9 y Berní, Práctica criminal con nota de los delitos, 2.

36 Hespanha, "Una historia de textos".

37 Berní, Práctica criminal con nota de los delitos, 2. 
of a more important knowledge power: the observed practice of the Courts. But this should not come as a surprise. Elizondo, in the first volume of his Practica Universal Forense, wrote that:

You will find a plan, that I consecrate to the wise, and to the curious, to delineate in it the brush of the Juridical. Without being able to vanish the novelty of my Work, the writings of Paz, and Villadiego; For if you do me justice, you will know the concession of these in the variety of resources, produced by the diversity of the Tribunals of our Monarchy, their juridical exposition, and other singular things, which I try to demonstrate with the Royal dispositions, subsequent to the Work of those, of Monarchs so exalted with which Spain has boasted. ${ }^{38}$

In contrast with jurisprudential knowledge, the recursive and daily knowledge of the tribunals would appear. This task would be mostly known through observation. On the other hand, the force of the legislative power appears to mark that the previous works had not contemplated "the real dispositions" dictated after their publication. This attack shows that the quality of the work resided in the "updated" knowledge of practice and the law of the King. This statute broke the logic of centuries where knowledge was ancient because it was good, while here beyond goodness it was topicality that mattered. ${ }^{39}$

It is interesting, then, to see how the same logic of constitution of a disciplinary field - in this case, the practical one - at the very moment of recognising antecedents for settling down and founding tradition, it carries out a torsion that disqualifies that past in order to justify the present of writing. Consequently, the political ingenuity codified, in part, in the weeding of an abundance of opinions that opened the space for the application of the law, allows us to think of its mediation and functionality in a process of autonomisation of judicial practice with respect to a theory of iuris opinio. This history that, with the passage of time, would separate dogmatics from the practice of the courts, had to do with the constitution of a field of knowledge that, having departed from a tradition that did not separate theory and praxis, discarded the former, returning the daily life of the judicial task to a set of uses and

38 Elizondo, Práctica, vol. 1, Prólogo. The premise for reducing the vast literary universe of ius commune was a characteristic that marked the long period from the 18th century to the times of codification. On this subject, see the outstanding study Mohnhaupt, "'Historia literaria iuris'".

39 See Duso, La lógica del potere, 57: "Il buon diritto antico non era buono perché antico, ma antico perché buono". 
practices. So, gradually detaching itself from voices that were becoming more dangerous every day, legal actions - subject to description - lost the knowledge that justified them, turning the process into a form without tradition, a pure form, a practice.

Up to this point, the relations between political and literary cultural formations were evaluated, which allowed, in their timed action, the production of a decentralised practical sense of the theory. However, this had an impact on the discursive formation that conveyed this new knowledge, without ignoring the fact that these rules of writing and the production of knowledge about practices also influenced the political and cultural fields.

\section{$5 \cdot 3$}

\section{The Writing of Practices}

As noted, the purpose of these texts was their utility, which referred to advice for everyday judicial practice. This implied, in the first place, reaching those users who could benefit from a practical book. The consideration of the reader, who acted as a horizon of expectation for the practical authors, determined the form of writing..$^{40}$ Both elements cannot be separated from a material condition. Since the 17 th century, there had been technological and economic reasons that explained the accelerated tendency of the passage in the language of books from Latin to romance. This did not necessarily mean that the first texts lost their value - in economic and symbolic sense - in the Castillian linguistic space, ${ }^{41}$ but they were linked more to places of status than to rapidly expandable technologies of knowledge. Within this particular literature, Villadiego found a close relationship between language and the influence of "forensic practices" by stating:

And to go in romance this book, has in itself particular grace, and usefulness, so that those who do not know Latin, are not deprived of these matters, and things so common, that it is convenient for them to know; without this seeming to be less, nor profane this science, because in all vulgar languages this is the most abundant, virile, and sonorous, and most common to various nations of the world. ${ }^{42}$

40 Chartier, The order of Books, 27.

41 Chartier, El presente del pasado.

42 Villadiego Valcuñana y Montoya, Instrucción Política y práctica judicial, Prólogo. A similar piece of news about this writing practice and the main model that marks the production threshold in Spanish is the classic book by Castillo de Bovadilla, Politica para corregidores. For an excellent commentary on this author and the production of his work, see Francisco Tomás y Valiente, "Castillo de Bobadilla. Semblanza personal y profesional de 
With a more pragmatic vocation based on observation, Fernández de Herrera Villarroel said:

[...] Scribes of these Reynos are not Latinos. I believe that some practices that are [written] in that language are no longer useful for the majority of scribes, nor others that in Latin, and Romance annoy those who look at the Glossa, do not understand the text, or on the contrary, and that although some and others say what should be done, they lack the when, and why, and the forms of autos, and in them many difficulties are not touched that the modern experienced have recognized. ${ }^{43}$

Texts written in Spanish reached an audience that needed to know, through this translation, the theory behind everyday life. This translation was not minor, since although in several works some quotations appeared in Latin, their content, their formulations, the re-submissions sought to reduce "the multitude of allegations, decisions, and consultations scattered in so many books". With this, young people were "pleased with a study, about which, being taught without rules to dispute everything from the beginning, they would surrender a few times later with submission to the just and innocent uses of the forum". 44

The composition of the page in the simplicity of Spanish also operated as a reflection of the size of the works, which sought to be cultural objects of easy circulation. An example can be found in the authorisation of Joseph Bernís practice: "Perfection, which the Author of this succinct work also obtained from our [laws], making sure with its smallness, and manner accommodated to everybody, that it can go in the hands of everyone, even of those that will not reach them in their originals, because of their high price or their voluminosity". ${ }^{\prime 4}$ Elizondo warned of the same thing when he said: "[...] it does not serve us as an impulse to write the vain ambition of fame, or any other less patriotic spirit, than that of reducing many volumes to a few, distracting them by a precise order, and dictating them without affectation, subtlety, or darkness in relief of the youth".46

However, this romance language opening within the legal literary traditionwritten in Latin - deserved an apology from the authors. This compromised

un juez del Antiguo Régimen", in Tomás y Valiente, Gobierno e instituciones en la España del Antiguo Régimen, 179-251.

43 Fernández de Herrera Villarroel, Practica criminal, instrucción (nueva útil) de substanciar las causas, Prólogo al lector.

44 Elizondo, Práctica, vol. 4, vili.

45 Berní, Práctica criminal con nota de los delitos, Authorisation of 22 September 1749.

46 Elizondo, Práctica, vol. 1, Prólogo. 
situation, faced with the possible reprobation of the lawyers, highlighted the interest of reaching laymen, rescuing the "practical" sense of the book. In Villadiego's work, these elements were synthesised in a flowery paragraph:

And this book is not of lesser esteem, because it is taken out of other Authors, so that more credit is given to what is written here, and I want it to be understood, than to dare to write, and to bring this work to light. $[\ldots]$ For the taste of the Reader, we have tried to meddle with the things of usefulness that are resolved here, some of them of taste, because what Horatio said is fulfilled, that the perfect work must have usefulness and taste. $^{47}$

The same thing happened in the book written by Fernández de Herrera Villarroel, who, after recounting the fear of publishing his work, and the insistence of a friend to do so, said:

What I surrendered to, was to say, that I did not write for savants, to whom these principles do not take advantage, but is, or for those who ignore (or those who are forgotten) for being as it is true, that so much of this genre has not been gathered so far in our Spanish language. There are so many books that give documents which explain how not to sin, and so many for punishment (which corresponds to the crime after having been committed), but there was none of them about the practice, and theoretical together, that were in between, and led to that purpose. ${ }^{48}$

A double mediation appears here: the first between practical and theoretical; the second between wise and lay. It is also interesting to note the vacuum that his work filled, by presenting his work as a medium. All this indicates that the hiatus was both human and literary.

Towards the middle of the 18th century, Elizondo also debated between both audiences, but with a stronger tone and, given the contextual conditions outlined above, he declared:

We, far from being resentful of any observation, addition, or correction that the Wise subscribe to, sincerely protest to embrace them with humility and gratitude, knowing that their spirit is not to discredit our works,

47 Villadiego Valcuñana y Montoya, Instrucción Política y práctica judicial, Prólogo.

48 Fernández de Herrera Villarroel, Practica criminal, instrucción (nueva útil) de substanciar las causas, Prólogo. 
but to help them to perfection, in order to make them more interesting to the Republic of Letters; [...] which would disprove the good intention, which encourages us, and we proposed, of course, to aspire to the common good only of young people. ${ }^{49}$

In the same sense, giving an account of his previous ignorance, Álvarez de Posadilla pointed out that his work was addressed to "those who exercise the office of Notary, to the Ordinary Mayors, and even to new Judges, I have thought it convenient to give it to the press, so that its usefulness is not limited to the disciple to whom it has been given", 50 for his part, as for his person he confessed, "besides the ideas and knowledge acquired from many things that he did not know, to have come out of a great number of errors that as legal practices he had learned from his Master". ${ }^{1}$

The combination of language, size of works and readers in the constitution of the literary genre also impacted on the conceptual logic of forensic practices, which was devalued by their lack of correlation with profound knowledge. ${ }^{52}$ This devaluation, however, was, as previously presented, the consequence of a political-cultural change that, far from implying a teleological gaze, evidenced a new form of production of practical knowledge. Now, at this point it seems that this history of books has no correlation with bodies and justice. In order to connect the experience with the cultural field that coded it, the observation has to return to the experience of the Río de la Plata at the end of the 18th century, which will be used here to discern the way in which these practical ideas materialised in Spanish American territories.

\section{Transferability of Practices: Know-How and Institutions}

The political change inscribed in the two different ways of conceiving the practices would take shape in the ways of organising the spaces of jurisdictional power. ${ }^{53}$ For the sake of brevity, here are some clues to understand the territory of the Viceroyalty of the Río de la Plata, especially during the 18th century. When facing a century of profound cultural changes, the effects would be felt dissimilarly in an extended space. In this context, the heuristic model of Mario

49 Elizondo, Práctica, vol. 4, IX.

50 Álvarez de Posadilla, Práctica criminal por principios, II.

$5^{1} \quad$ Álvarez de Posadilla, Práctica criminal por principios, Prólogo.

52 Bajtín, Estética de la creación verbal.

53 Barriera, Abrir puertas a la tierra; Hespanha, La Gracia del Derecho. 
Sbriccoli allows us to better understand the development of institutions by opposing a negotiated to a hegemonic justice. ${ }^{54}$ This framework serves as a window into the operability of criminal practices, taking into account the conceptual distance between those written during the 17th century - widely circulated and used during the 18th century - with respect to those actually written in the 18th that, as a novelty, would have an impact on the Bourbon reformers.

Within the great framework proposed, the judiciary of the 17th and 18th centuries, in peripheral areas, presents typical traits of a negotiated justice. A justice of neighbours that implied techniques of government, which carried with them centuries of political tradition. The negotiating role, arbitrator of the problems of a political body, was central. Thus, it not only composed problems of the community but also solved dualisms of the legal universe - between the power of law and judgement, between ordinary and extraordinary ways, in the mixture of accusation and inquisition, between punishment and forgiveness. ${ }^{55}$ This preeminent role of the judge and the consequent harmonisation composed a grammar where justice, equity and reasonability stood out. If we add to this the fundamentally lay character of the magistracy, it seems that what can be said and practiced in this context depended on the judge. However, this did not imply that the magistrates acted without a guide, and above all, at the time of writing, they were formulating the account of what happened and forwarding the documents from one seat of justice to another, mainly for control or review. This was complicated especially by the possibility of being sanctioned. In that context, the practices functioned as a textual regulator, as evidenced by the similarity documented in the archives.

Precisely, Alejandro Agüero has stated that, in the 18th century, there were three key elements of influence in the work of laymen. ${ }^{56}$ The first concerned the notaries. The absence of lawyers functioning as judges required the revision by a legal advisor, who instructed and transmitted knowledge. In the absence of notaries, the dominant ecclesiastical presence established mechanisms of control of what could be done, with a jurisdictional knowledge that modulated the writing of the cases. ${ }^{57}$ Finally, Agüero points out that there was "a constant

54 Sbriccoli, "Justicia Criminal"; Meccarelli, "La dimensión doctrinal del proceso desde una perspectiva de historia de la justicia criminal".

55 Meccarelli, "Dimensions of Justice and Ordering Factors in Criminal Law from the Middle Ages till Juridical Modernity", 62-63; Agüero, Castigar y perdonar cuando conviene a la República.

$5^{6}$ Agüero, "El testimonio procesal y la administración de justicia penal en la periferia de la Monarquía Católica", 6-7. See Barral, De sotanas por la Pampa; Barriera, "Voces legas, letras de justicia”, 352-353. 
and silent factor: the circulation of legal books and manuals of procedural and notarial practices among the principal members of the neighbourhood".58 These practical books had a great impact, even if their content escaped the full understanding of high literature. It is precisely because they helped to label the actions of the community in a certain culture of order. Principally, this becomes visible in the body of the texts which not only ordered the crimes, the penalties, the methods of proof, the auxiliaries involved in the substance of the process, etc., but which included the syntactic formulas of writing down the steps of the process: the autos and so on. Hence, everyday life was filled with concepts by which the writers transmitted fundamental meanings.

As we enter the 18th century this textual production was conveyed by new institutional ends. Hence, in addition to these three modes of expansion of procedural knowledge of a local character, a growing control device had to be added - from the second half of the 18th century on - that was not only given by the presence of Bourbon officials but also by the Real Audiencia of Buenos Aires. As I have analysed in another paper, ${ }^{59}$ this Court added several elements of control, motivated by a series of prejudices against laymen. As Agüero points out, these prejudices were - more than being anchored in the lack of jurisdictional precision - activated by a logic of distinction, and functioned as a legitimating discourse of European lawyers faced with a justice exercised by American neighbours. ${ }^{60}$ Beyond the veracity or not of the reasons exposed by the Audiencia and its criticism of the practices of the laymen, the purpose of empowerment of the Audience can show the close relationship between the texts of the practices and the institutional dynamics.

If utility had produced, towards the middle of the 18th century, a separation of the practice from the theoretical armour that made up its base and essence, the desire for uniformity found an effective control device in malleable practices. In this way, practices were performed as a regulatory task. An example of this is given in a frustrated attempt in 1788. Within the Real Audiencia de Buenos Aires, the Regent Mata Linares projected a "Circular Instruction for the best and shortest dispatch of the formation of criminal cases", which, although never sanctioned by the delay of Prosecutor Márquez de la Plata, sought to

$5^{8}$ Agüero, "El testimonio procesal y la administración de justicia penal en la periferia de la Monarquía Católica", 7 .

59 Casagrande, "Erradicando sus rústicos juzgamientos".

6o On this aspect, see Agüero's interesting discussion, referring to a classic work by Mariluz Urquijo on the relations between laymen and lawyers. See Mariluz Urquijo, "La Real Audiencia de Buenos Aires y la Administración de Justicia en lo criminal en el interior del virreinato"; Agüero, "Saber jurídico y técnica procesal en la justicia lega de la periferia". 
unify the procedural practice of justice. In this document there was an attempt to normalise the daily practices in order to avoid that the hightest tribunal wasted its time rectifying the actions, and at the same time, in order to avoid the apologies of the subaltern justices who, by their ignorance or malice, harmed the vindicta pública. Now, when presenting the memoria document to his successor, Mata Linares emphasised that the Instruction had been "taken from what the laws provide and from our best practicians, clear, methodical and comprehensive of the formalities to be observed". ${ }^{11}$ One example, which goes back to literary practices, were the forms, which were interspersed between the provisions to be followed by judges in the investigation. Articles 19 and 20 of the above-mentioned draft are an example:

$19^{\circ}$ The office of the Judge will serve as prosecutor in the slight cases, and this until issuing an order of guilt and charge to the defendant, and giving him notification so that he can defend himself in this, or an equivalent form: $20^{\circ}$ In that Villa or Partido, on that day of that month of that year, Don XXX, etc. Having seen the summary information against XXX, because of this, or of the other crime, he said: That from this information and from the confession, it turns out that said defendant committed such and such of the crimes, and that this, in the best possible way in law, made him guilty, and charged him, and of course he gives him notification, so that within nine days he shall purge himself, and at the end of which he would receive, and I receive the cause for evidence with all charges of conclusion, publication and summons, in order to hear sentence, and that the witnesses of the summary trial be confirmed. And so it was ruled, commanded and signed, acting for me, and before witnesses in the absence of a notary. ${ }^{62}$

The procedural matter was ordered without requiring further knowledge. It was intended for "those who had no appreciation for reading" and yet acted as judges. The regulation that, as a new power was appearing in the territory, sought to give ground to the traditions of the judge-arbitrator guided exclusively by his prudence. The verification of facts, the forms of declarations, etc. prepared a culture of procedural practice that fulfilled the purposes of an administration, which in the scheme of powers was taking away space for mediation and opening the place to mere application.

61 Mariluz Urquijo, "La instrucción circular para el mejor y más breve despacho de la formación de las causas criminales", 177 .

62 Mariluz Urquijo, "La instrucción circular para el mejor y más breve despacho de la formación de las causas criminales", 186. 


\section{$7 \quad$ Conclusion: Beyond the Practices, the Languages}

Through institutional analysis, it can be seen how the pragmatic texts of prácticas criminales could extend into daily life. These late eighteenth century elements of discursive coercion and normalization make it clear that textual levels are not only related to each other when analyzing the history of books, but rather establish a set of relations of institutional preeminence between legal documents (books, judicial archives, laws, Bandos de Buen Gobierno, etc.). This, in turn, had an impact on historical reconstruction, reducing the impression of a total agency attributed to the actors and their practices by social history. As Michel Pêcheux stated:

Faced with a legal or scientific text, this difficulty [the delimitation of what belongs or does not belong to the corpus] does not seem to arise to the extent that there is, in this case, an institution (legal or scientific, etc.) to which the texts can refer. It is therefore necessary to point out the difference between the documentary analysis, carried out within an institutional reference for purposes that respond, in general, to those of the institutions, and the analysis that we will call "non-institutional". [...] Documentary analysis fundamentally requires that the equivalence would be defined a priori by the institutional norm itself. 63

Thus, the relationships between texts - archives, criminal practice, legislation, etc. - show a structure of analysis that requires to reveal the institutional logic underlying the discursive intersection. Between laymen and literate, between savants and rustic people, between levels of languages, the institutional power and the ends to which they responded - from the political government of the republic to the search for the procedural ordering of the Audiencia - produced an order of discourse that, without annihilating the actor, reduced his expressive capacity. At the same time, however, this does not imply a static dimension; rather, the changes in power structures and in the devices deployed to sustain it - jurisdiction, legislation, etc. - did have an impact on the logics of the sources of law. Correspondingly, these changes influenced the values attributed to the documents which are subject of current historiographic research.

In sum, one can observe that this literature and the hypotheses that accompany its composition are only an index of much greater problems, that

63 Pêcheux, Hacia el análisis automático del discurso, 29. 
escape the procedural legal matter, and when it comes to working between dogmatics, practice and the judicial archive, these texts require double epistemological vigilance. On the one hand, they draw attention to a deeper work on the knowledge covered by judicial saying, concealing a romanticisation of the practices in the daily life of the courts. On the other hand, given the difference between the syntactic structures reproduced by the judges in the cases that make up the archives today, it is possible to relate what is written with intermediate models that conveyed different visions of the political order. This is equivalent to saying that the comparison of the textuality of the archive with respect to the formal procedures of certain practices - Villadiego, Fernández de Herrera Villarroel - refers to knowledge that the present can ignore. Thus, criminal judicial practice is a true sounding box of languages and knowledge, whose reading opens the door to a political anthropology that allows us to recognise the symbolic universe which composed the normative culture in different spaces of the Spanish Monarchy - mainly through literature. ${ }^{64}$

\section{Acknowledgements}

This text is a revised version of an article published in Spanish: Casagrande, "Literatura Práctica en el siglo XVIII". The English translations of all the Spanish and French quotations included in this chapter were done by the author.

\section{Bibliography}

\section{Printed Sources}

Álvarez de Posadilla, Juan, Práctica criminal por principios o modo y forma de instruir los procesos criminales de las causas de oficio de justicia, Madrid 1798: Imprenta de la viuda de Ibarra.

Berní, Joseph, Práctica criminal con nota de los delitos, sus penas, presunciones, y circunstancias que los agravan y disminuyen; y ritual para Juzgar, acriminar, Valencia 1741: Simón Fauré.

Elizondo, Francisco Antonio de, Práctica universal forense de los tribunales de España, $y$ de las Indias, 8 vols., 4th impr., Madrid 1783-1788: D. Joachin Ibarra Impresor de Cámara de S.M.

64 See Martínez and Agüero, "Ein Gespräch mit ... Bartolomé Clavero". 
Fernández de Herrera Villarroel, Gerónimo, Practica criminal, instrucción (nueva útil) de substanciar las causas, con distinción de lo que particularmente parece se debe observar, assi en los Consejos, y Sala, como en otros Tribunales superiores, y en los inferiores de Juezes pesquisidores, y ordinarios, por los Escrivanos á quienes suelen cometerse, en que se notan muchas de las dificultades que se ofrecen en el todo, y en parte de ellas, Madrid 1724: Imprenta de Don Gabriel del Barrio.

Real Academia Española, Diccionario de la lengua castellana, en que se explica el verdadero sentido de las voces, su naturaleza y calidad, con las phrases o modos de hablar, los proverbios o refranes, y otras cosas convenientes al uso de la lengua [...]. [Diccionario de Autoridades], 6 vols., Madrid 1726-1739.

Real Academia Española, Diccionario de la lengua castellana [...], 1oth ed., Madrid 1852. Villadiego Valcuñana y Montoya, Alonso de, Instrucción Política y práctica judicial, conforme al estilo de los Consejos, Audiencias, y Tribunales de Corte, y otros ordinarios del Reyno. Utilissima para los Governadores, y Corregidores, y otros juezes ordinarios y de comisión, y para los Abogados, Escrivanos, Procuradores y Litigantes, Madrid 1720: Imprenta de Juan de Ariztia.

\section{Literature}

Agüero, Alejandro, "Saber jurídico y técnica procesal en la justicia lega de la periferia. Reflexiones a partir de documentos judiciales de Córdoba del Tucumán, siglos XVII y XVIII", in Aguilar, M. Torres (ed.), Actas del XV Congreso del Instituto Internacional de Historia del Derecho Indiano, vol. 1, Córdoba 2005, 311-332.

Agüero, Alejandro, "Las categorías básicas de la cultura jurisdiccional", in Lorente Sariñena, Marta (ed.), De justicia de jueces a justicia de leyes: hacia España de 1870, Madrid 2006, 19-58.

Agüero, Alejandro, Castigary perdonar cuando conviene a la República. La justicia penal de Córdoba del Tucumán, siglos XVII y XVIII, Madrid 2008.

Agüero, Alejandro, "El testimonio procesal y la administración de justicia penal en la periferia de la Monarquía Católica, Siglos XVII y XVIII", in Fontes 1 (2014), 3-14.

Aguirre, Carlos and Ricardo Salvatore, "Writing the History of Law, Crime, and Punishment in Latin America”, in Salvatore, Ricardo, Carlos Aguirre and Gilbert Joseph (eds.), Crime and Punishment in Latin America, Durham 2001, 1-32.

Bajtín, Mijaíl, Estética de la creación verbal, Buenos Aires 2002.

Barral, María, De sotanas por la Pampa. Religión y sociedad en el Buenos Aires rural tardocolonial, Buenos Aires 2007.

Barriera, Darío, "Voces legas, letras de justicia. Las culturas jurídicas de los legos en el Río de la Plata entre los siglos XVI y XIX", in Mantecón Movellán, Tomás A. (ed.), Bajtin y la historia de la cultura popular, Santander 2008, 347-368.

Barriera, Darío, Abrir puertas a la tierra. Microanálisis de la construcción de un espacio político. Santa Fe, 1573-1640, Santa Fe, NM 2013. 
Barriera, Darío, "La historia de la justicia y las otras historias", in Richard-Jorba, Rodolfo and Marta S. Bonaudo (eds.), Historia Regional. Enfoques y articulaciones para complejizar una historia nacional, La Plata 2014, 19-40.

Bernal, Beatriz, "Las leyes de Indias a la luz de dos comentaristas novohispanos del siglo XVIII", in Revista Chilena de Historia del Derecho 9 (1983), 325-354.

Bien, Günther, Theo Kobusch and Heinz Kleger, "Praxis, praktisch", in Ritter, Joachim and Karlfried Gründer (eds.), Historisches Wörterbuch der Philosophie, vol. 7, Basel 1989, 1277-1307.

Bourdieu, Pierre, "Le champ scientifique", in Actes de la recherche en sciences sociales 2 (1976), 88-104.

Bourdieu, Pierre, El sentido práctico, trans. Ariel Dilon, Buenos Aires 2007.

Buffington, Robert, "Introduction: Conceptualizing Criminality in Latin America", in Aguirre, Carlos and Robert Buffington (eds.), Reconstructing Criminality in Latin America, Wilmington, DE 2000, XI-XIX.

Burke, Peter, Was ist Kulturgeschichte?, trans. Michael Bischoff, Bonn 2005.

Casagrande, Agustín, "Erradicando sus rústicos juzgamientos. La Real Audiencia y las justicias menores de Buenos Aires, 1785-1787", in Sudhistoria 5 (2012), 15-40.

Casagrande, Agustín E., "Literatura Práctica en el siglo XVIII. El orden procesal en la historia de la justicia rioplatense", Revista de Historia del Derecho 49 (2015), (http:// ref.scielo.org/zky3tz).

Cerutti, Simona, "Histoire pragmatique, ou de la rencontre entre histoire sociale et histoire culturelle", in Tracés 15 (2008), 147-168 (https://journals.openedition.org/ traces/733).

Chartier, Roger, The order of Books. Readers, Authors, and Libraries in Europe between the Fourteenth and Eighteenth Centuries, Stanford, CA 1992.

Chartier, Roger, El presente del pasado. Escritura de la Historia, Historia de lo Escrito, trans. Marcela Cinta, México 2005.

Chignola, Sandro and Giuseppe Duso, Historia de los conceptos y filosofía política, Madrid 2009 .

Costa, Pietro, Iurisdictio: semantica del potere politico nella pubblicistica medievale (1100-1433), Milano 2002 (1st ed. 1969).

Cutter, Charles R., The Legal Culture of Northern New Spain, 1770-1810, Albuquerque, NM 1995 .

De Certeau, Michel, La invención de lo Cotidiano.Las artes de hacer, México 2000.

Duso, Giuseppe La lógica del potere. Storia concettuale como filosofía política, Milano 2007 .

Fradkin, Raúl, La ley es tela de araña. Ley, justiciay sociedad rural en Buenos Aires, 17801830, Buenos Aires 2009.

Garriga, Carlos, "Sobre el gobierno de la justicia en Indias (Siglos XVI-XVII)", in Revista de Historia del Derecho 34 (2006), 67-16o. 
Giddens, Anthony, The Constitution of Society. Outline of the Theory of Structuration, Cambridge 1984 .

Habermas, Jürgen, Teoría y praxis. Estudios de filosofía social, trans. Salvador Mas Torres, Carlos Moya Espí, Madrid 1987.

Hespanha, António Manuel, "Una historia de textos", in Tomás y Valiente, Francisco (ed.), Sexo Barroco y otras transgresiones premodernas, Madrid 1990, 187-196.

Hespanha, António Manuel, La Gracia del Derecho: Economía de la Cultura en la Edad Moderna, Madrid 1993.

Mariluz Urquijo, José María, "La Real Audiencia de Buenos Aires y la Administración de Justicia en lo criminal en el interior del virreinato", in Primer Congreso de Historia de los Pueblos de la Provincia de Buenos Aires, La Plata 1952, 271-291.

Mariluz Urquijo, José María, "La instrucción circular para el mejor y más breve despacho de la formación de las causas criminales. 1788, proyectada por el Regente Benito de la Mata Linares", in Revista del Instituto de Historia del Derecho 12 (1961), 173-198.

Martínez, Fernando and Alejandro Agüero, "Ein Gespräch mit ... Bartolomé Clavero", Forum Historiae Iuris (2008), (https://forhistiur.de/20o8-o3-aguero/).

Meccarelli, Massimo, "La dimensión doctrinal del proceso desde una perspectiva de historia de la justicia criminal, a la luz de la lección historiográfica de Mario Sbriccoli", in Madero, Marta and Emanuele Conte (eds.), Procesos, inquisiciones, pruebas: homenaje a Mario Sbriccoli, Buenos Aires 2009, 13-37.

Meccarelli, Massimo, "Dimensions of Justice and Ordering Factors in Criminal Law from the Middle Ages till Juridical Modernity", in Martyn, Georges, Anthony Musson and Heikki Pihlajamäki (eds.), From the Judge's Arbitrium to the Legality Principle. Legislation as a Source of Law in Criminal Trials, Berlin 2012, 49-67.

Miceli, Paola, Derecho consuetudinario y memoria. Práctica jurídica y costumbre en Castilla y León (siglos XI-XIV), Madrid 2012.

Miceli, Paola, Práctica jurídica y costumbre en Castillay León (siglos XI-XIV), Madrid 2012.

Mohnhaupt, Heinz, "Potestas legislatoria und Gesetzesbegriff im Ancien Régime", in Mohnhaupt, Heinz, Historische Vergleichung im Bereich von Staat und Recht. Gesammelte Aufsätze, Frankfurt am Main 2000, 221-273.

Mohnhaupt, Heinz, "Historia literaria iuris: Beispiele juristischer Literaturgeschichten im 18. Jahrhundert ('Historia literaria iuris': Examples of Juridical Literary Histories in the 18th Century)", Max Planck Institute for European Legal History Research Paper Series No. 2013-03 (https://ssrn.com/abstract=2256530).

Palacio, Juan Manuel and Magdalena Candioti (eds.), Justicia, política y derechos en América Latina, Buenos Aires 2007.

Pêcheux, Michel, Hacia el análisis automático del discurso, Madrid 1978.

Sánchez González, Ramón, "La cultura de las letras en el clero capitular de la catedral toledana", in Aranda Pérez, Francisco José (ed.), Sociedad y élites eclesiásticas en la España moderna, Cuenca 200o, 163-236. 
Sbriccoli, Mario, "Justicia Criminal”, in Fioravanti, Maurizio (ed.), El estado moderno en Europa. Instituciones y derecho, Madrid 2004, 159-196.

Tau Anzoátegui, Víctor, La ley en América Hispana: Del descubrimiento a la emancipación, Buenos Aires 1992.

Thomas, Yan, "La valeur des choses. Le droit romain hors la religion", in Annales 57:6 (2002), 1431-1462.

Thompson, Edward P., Costumbres en Común, Barcelona 2000.

Tomás y Valiente, Francisco, El derecho penal de la Monarquía absoluta (Siglos XVIXVII-XVIII), Madrid 1969 .

Tomás y Valiente, Francisco, Gobierno e instituciones en la España del Antiguo Régimen, Madrid 1982. 